\title{
Capital Flight to Savings Gap in Nigeria: An Assessment of the Socio-Economic Determinants
}

\author{
Chukwuma Dim ${ }^{1} \&$ Uju Ezenekwe ${ }^{2}$ \\ ${ }^{1}$ Centre for Infrastructure, Policy, Regulation and Advancement, Lagos Business School, Pan-Atlantic University, \\ Nigeria \\ ${ }^{2}$ Department of Economics, Nnamdi Azikiwe University, Awka, Nigeria \\ Correspondence: Chukwuma Dim, Centre for Infrastructure, Policy, Regulation and Advancement, Lagos Business \\ School, Pan-Atlantic University, Km 22, Lekki-Epe Express way, Ajah, Lagos, Nigeria. Tel: 234-80-693-1198. \\ E-mail: chukwumad@gmail.com
}

Received: October 29, 2013

Accepted: November 28, $2013 \quad$ Online Published: January 23, 2014

doi:10.5539/ijef.v6n2p75

URL: http://dx.doi.org/10.5539/ijef.v6n2p75

\begin{abstract}
Capital Flight has long been recognized as a problem for developing nations. Savings gap in some of these nations has widened over the years due to rising Capital Flight. This has limped domestic investment growth, employment creation and poverty alleviation. With these in view, this study seeks to underscore the socio-economic determinants of Capital Flight in Nigeria. Approaching the study, two measures of Capital Flight (hot money method and residual method) are modeled against a number of socio-economic factors identified in the literature. Fully Modified Ordinary Least Square, Seemingly Unrelated Regression and Error Correction Mechanism are employed to sieve out the significant determinants of Capital Flight in Nigeria. Amongst the host, only lagged Capital Flight, fiscal balance and exchange rate are found to be the significant determinants of Capital Flight in the country. The study concludes that unless sound macroeconomic measures are taken to address these factors, Capital Flight will remain high in Nigeria. Domestic investment will remain very low. Poverty levels will remain high, and the quest for economic development will remain elusive. The key out of Nigeria's colossal savings gap is keeping domestic capital at home. This is achievable using the strategies discussed in the study.
\end{abstract}

Keywords: capital flight, savings gap, investment, unemployment, economic development

\section{Introduction}

Economic development and modernization has long been linked to technological advancement, which is connected to sustained investment and capital formation. While Domestic savings is the major source of capital formation, in its shortage foreign aid and debt has been resorted to. The problem with most developing nations, which has been established quite a long time ago, is low capital formation - simply inadequate domestic savings, savings gap. This, in some contexts, is believed to be as a result of the very fact that these nations are poor and, as such, investment needs tend to always outweigh the available savings.

According to Bender \& Lowenstein (2005), Savings gap exists when domestic savings are low to finance needed investment; and development finance from foreign debt comes handy in closing the savings gap and stimulating growth and development. Also, savings gap is generally defined as the difference between capital formation and the savings of an economy over a given period; it measures the economy's need for external funds (Galizia \& Steinberger, 2001). Rising savings gap has equally been linked to worsening Balance of Trade. Balance of Trade is used as a measure of a nation's savings gap.

Nigeria's need for foreign capital to augment its domestic savings, which at the moment is paltry, cannot be over emphasized. That the nation, however, witnesses rising Capital Flight, which manifests in various measures, remains a puzzle (see Ajayi, 1992; Ojo, 1992; Nyatepe-Coo, 1994; Ajayi, 1995; Onwiduokit, 2001; Agu, 2006; Ajilore, 2010). According to Nyong (2003), Capital Flight should be conceived as any form of abnormal capital outflows from a developing country by economic agents (private or public with the intention of concealing such flows). Agu (2006) on the other hand conceives Capital Flight as all resident capital outflows legal or illicit from an underdeveloped/developing economy with huge capital constraint. This definition, according to him, is justified given that there is no scientific way of separating "normal" from "abnormal" flows. In addition, the consequences 
of capital outflows to the national economy are the same regardless of whether the outflow is normal portfolio diversification or abnormal flight.

Revealing the severity of Capital Flight in Nigeria, Chang \& Cumby (1991) in a cross-country study on Capital Flight from 36 sub-Saharan African countries from 1976 to 1987 found Nigeria to be the only country in the group with absolute level of Capital Flight greater than those of Latin American countries. Similarly, Ojo (1992) concludes that the cumulative Capital Flight from Nigeria between 1975 and 1991 was in excess of US\$35.9 billion, being more than double the total of the other two African countries (cote d' Ivore and Morocco) in the sample. Adedeji (2001), using World Bank (1985) definition of Capital Flight, presents statistics on the evolution of Capital Flight. The study reveals an annual average of US\$496 million during 1972-1979. This increased to US $\$ 1,478$ million in the pre-crisis period (1980-1986) and further increased to an annual average of US $\$ 3,071$ million during 1987-1994. Furthermore, Ajilore (2010) records that on the average more than US $\$ 18.8$ billion worth of capital was exported out of Nigeria annually between 1970 and 2004. He further states that not only is the country loosing substantial amounts of funds that could otherwise be used for development and further stabilization, but that Capital Flight also punishes long term economic growth. Maniak \& Milaszewicz (2008) note that "accumulation capability is determined by capital resource that may be used for development, and depends mainly on the capability of economy to economize, as high saving rate usually allows for high investment rate." Thus, Capital Flight, in our view, is anathema to expectations for Nigeria, given her level of economic development.

Figure 1 below helps bring the intensity of the problem to mind. As the figure reveals, the magnitude of the savings gap, measured by the non-oil trade deficit, in Nigeria has risen over the years. Yet, instead of foreign capital coming and staying to sustain investment in the country, both domiciled foreign capital and domestic capital is fleeing to, who knows, safer havens. More so, this widening savings gap reflects the ballooning Capital Flight in Nigeria, for as Bouchet (2012) notes, the larger the amount of Capital Flight, the larger the savings gap.

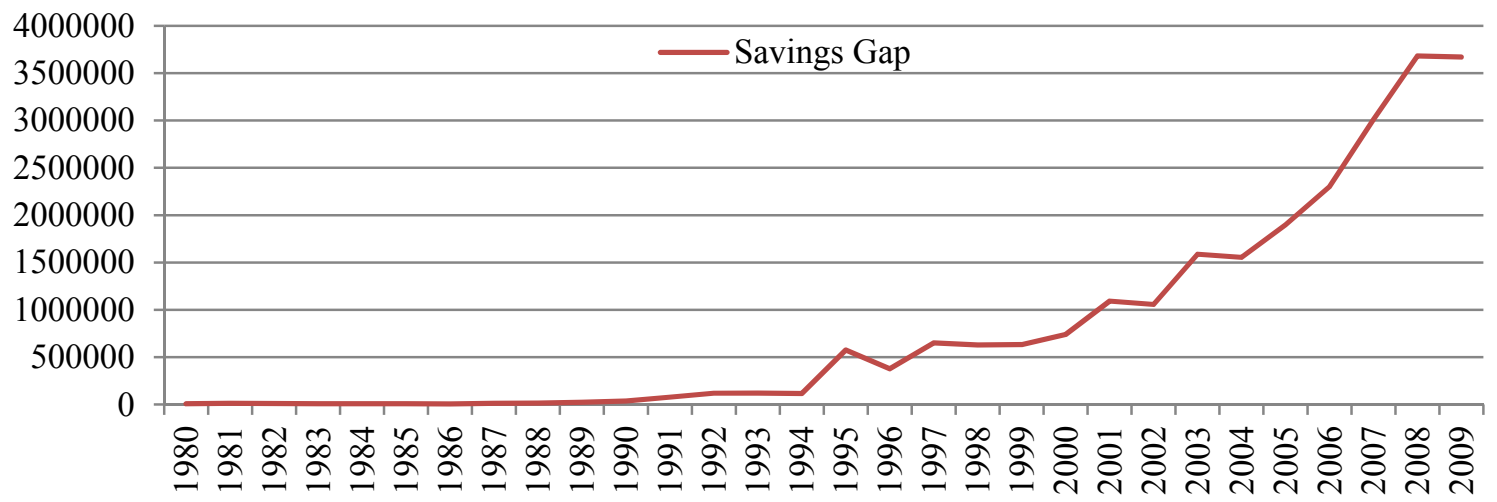

Figure 1. Magnitude and rising trend of savings gap in Nigeria

Source: Computed from the Central Bank of Nigeria's Statistical Bulletin 2010.

The above scenario is believed to be a big challenge to development in Nigeria. It limits the success of efforts made at employment creation and sustained economic growth. It impedes the success of government's growing focus on economic diversification and, thus, warrants a focused study on the determinants of Capital Flight in Nigeria.

Understanding that Capital Flight contributes to savings gap in Nigeria, this study proceeds to explore a host of socio-economic factors identified in the literature to account for Capital Flight in nations. The sole objective of the study, therefore, is to empirically ascertain the socio-economic factors that account for the observed Capital Flight in Nigeria. The findings of the study, which will be robust across techniques, will offer better understanding of the dynamics of the concept Capital Flight in developing nations. It will aid government policy at abating Capital Flight, hence achieving higher levels of domestic investment, employment creation and also reducing the pressure on certain macro-economic variables that are largely influenced by Capital Flight. 


\section{Literature Review}

\subsection{The Challenge of Defining Capital Flight}

According to Kindleberger (1987), there is no widely accepted definition of Capital Flight. The definitions associated with the concept of Capital Flight are divergent, with varieties of meanings implied, and the word "flight" itself used to connote illegal movement of capital from one country to another. Given this, various attempts have been made to define the concept in various contexts. Lessard \& Williansom (1987) refers to "Capital Flight" as capital that "runs away" or "flees" abnormal risk at home regardless of whether or not the flight is legal.

At the broad extreme, it has been defined to include all private capital outflows from developing countries (Kahn \& Hague, 1987), while at the narrow extreme it includes only illegal capital exports (Lessard \& Williamson, 1987). The broad perspective takes into consideration all private capital outflows from a developing economy. By this definition, all private capital outflows from developing countries, be they short term or long term, portfolio or equity investments, could be termed Capital Flight. This is because developing countries are generally considered to be short of capital and should therefore be net borrowers in the development process, supplementing domestic savings with external finance.

In line with the above, Kindleberger (1987) and Walter (1987) broadly define Capital Flight as all capital that "flees" irrespective of the motive. Similarly, Morgan Guaranty Trust Company (hereafter Morgan Trust, 1986) defines Capital Flight as reported and unreported acquisition of foreign assets by the non-bank private sector and some elements of the public sector. Loosely put, Eggerstedt et al. (1995) define Capital Flight as the unreported private accumulation of foreign assets. Alternatively, Capital Flight can be considered as the change in the private sector's net foreign assets (World Bank, 1985; Erbe, 1985; Morgan Trust, 1986; Chang \& Cumby, 1991).

Proceeding, some researchers regard only short-term outflows resulting from economic and political uncertainties in the home country as Capital Flight. In other words, it is money that is fleeing from the country rather than external investment guided by long term economic considerations. Therefore, Capital Flight could be defined as the difference between total private capital outflows and the part for which interest income is identified and reported (Kahn \& Hague, 1987).

The above panorama of Capital Flight shows that the term cannot be exhaustively conceived from a particular perspective. However, for the purpose of this study, we adopt the definition given by Agu (2006): all resident capital outflows legal or illicit from an underdeveloped/developing economy with huge capital constraint.

\subsection{Measuring Capital Flight}

Lack of a general consensus on the conception of Capital Flight translates to a disagreement on an objective measure of the concept. Various measures depending on the definition one is enamored with have been adopted over the years. In this study, we focus on two measures of Capital Flight that has been widely employed by researchers over the years: "Hot money approach" and the "Residual approach".

The Hot money approach was offered by Cuddington (1986). The main claim he made was that the regular capital flows, explained by portfolio diversification goals, corresponds to long-term flows, while the short term flows consist of Capital Flight. In the broadest form, this measure is calculated as a sum of net errors and omissions (NEO) and the recorded capital outflows from the private sector. The narrow measure is defined simply as net errors and omissions from the balance of payments statistics. This study will adopt the broad measure shown in equation 1 below.

$$
C F=G+C+D
$$

Where, CF is Capital Flight; $\mathrm{G}$ is Errors and Omissions; C is Private short-term Capital Outflows; and D is Portfolio Investment Abroad (Bonds + Equities).

The "Residual approach" has been the most widely used measure of Capital Flight in the literature. The method acknowledges the difficulties of separating abnormal from normal capital outflows and, therefore, measures all private capital outflows as being Capital Flight. Several variations on the measure have appeared in the literature, among them World Bank (1985), Morgan Guaranty (1986) and Cline (1987). The residual method obtains an indirect measure of Capital Flight by comparing the "sources of funds" and "uses of funds." According to the World Bank residual method, Capital Flight is given by equation below.

$$
C F=\triangle E x D+N F D I-C A D-\triangle I R
$$

Where, $\mathrm{CF}$ is Capital Flight; $\triangle \mathrm{ExD}$ is the changes in external debts; NFDI is the net foreign direct investment; $\mathrm{CAD}$ is the current account deficit; and $\triangle \mathrm{IR}$ is the changes in international reserves. 


\subsection{Determinants of Capital Flight, Widening Savings Gap}

The possible determinants of Capital Flight have been highlighted by various theories, such as the investment diversion theory and debt driven Capital Flight thesis, amongst others.

The Investment Diversion Theory of Capital Flight postulates that due to the macroeconomic and political uncertainties in developing countries, and the simultaneous existence of better investment opportunities in advanced countries, like high foreign interest rates, wide array of financial instruments, political and economic stability, favorable tax climate and secrecy of accounts, some unscrupulous, corrupt leaders and bureaucrats usually siphon scarce capital resources from their countries to advanced countries. They do this either to earn higher returns, safe guard there investment from instability, diversify their assets, or to enjoy confidentiality. These funds are, therefore, not available for investment at home, thereby widening the savings gap, constraining aggregate investment and limping economic growth. As Skare \& Sinkovic (2013) noted, investment growth policy enhances and sustains long-term growth. Capital Flight does the opposite.

The Debt Driven Capital Flight Thesis, which is a continuation of the investment diversion thesis, postulates that given the heavy external debt of a country, residents of these countries are motivated to move their resources outside the country to foreign countries. Borrowed money is sold to domestic economic agents by way of wage payments and transfers; these agents shift these funds partly or completely abroad. According to this theory, external debt is one of the propellants or fuel to Capital Flight. Rising domestic debt reduces the incentive to save and invest in an economy. The assumption here is that with large foreign debt, there are expectations of exchange rate devaluation, fiscal crisis, and the propensity of the crowding out of domestic capital and expropriation of assets to pay for the debt. Thus as residents get hold of their pay, saving or investing them in the country becomes an unacceptable consideration, given the negative macroeconomic expectation which the high debt has inflicted on the economy. Residents as a result transfer their funds to foreign countries where the risk of loss of gain or capital is low. The result is widening savings gap, economic stagnation.

Taking the investment diversion and debt driven theories of Capital Flight together, we summarize the main variables that influence Capital Flight around endogenous "push" factors and exogenous "pull" factors, i.e., whether these factors stem from the country's economic and sociopolitical systems, or from the magnet of the global economy respectively. This is summarized in table 1 below.

Table 1. Push and pull factors of capital flight

\begin{tabular}{lll}
\hline & (Internal) Push Factors & (External) Pull Factors \\
\hline $\begin{array}{l}\text { Political and Institutional } \\
\text { Factors }\end{array}$ & $\begin{array}{l}\text { Political upheaval; social instability; bad } \\
\text { governance; corruption }\end{array}$ & $\begin{array}{l}\text { Opacity and loose banking regulatory } \\
\text { framework; accommodative financial policies }\end{array}$ \\
Macroeconomic Factors & $\begin{array}{l}\text { Low or negative real interest rates, overvalued } \\
\text { exchange rates; inflationary pressure; capital } \\
\text { account liberalization; rising external indebtedness }\end{array}$ & $\begin{array}{l}\text { High external real interest rates, strong and } \\
\text { stable exchange rates of hard currencies }\end{array}$ \\
Microeconomic Factors & $\begin{array}{l}\text { Banking undercapitalization; liquidity crisis; } \\
\text { institutional weaknesses of the financial system; } \\
\text { rise in corporate income taxes; unregulated } \\
\text { financial system; stock market crisis }\end{array}$ & $\begin{array}{l}\text { Strong asset management competitive } \\
\text { advantage; dynamic offshore financial systems; } \\
\text { offshore tax havens; booming stock markets in } \\
\text { foreign countries }\end{array}$ \\
\hline
\end{tabular}

Source: Bouchet (2012).

Certain empirical studies have sought to verify the significance of the identified socio-economic pull and push factors. Henry (1996) examined the causes of Capital Flight for 3 Caribbean countries using time-series analysis over the period 1971-1987. The result reveals that external debt, real interest rate differentials and unemployment rate are significant causes of Capital Flight. Fatehi (1994) analyzed the impact of political disturbances on Capital Flight in 17 Latin American countries using stepwise multiple regression analysis on data between 1950 and 1982. The study concludes that political disturbances in some of those countries have effects on Capital Flight from these countries. Ndikumana \& Boyce (1998), using time series data, stipulates that Capital Flight in Zaire was stimulated by reckless debt management, multilateral depository and financial institutions that were too lenient in their lending practices, as well as by the misappropriation of export revenues. Nyoni (2000) employed time series analysis over 1973 to 1992 on Tanzania in analyzing the impact of some socio-economic variables on Capital Flight. He concludes that lagged Capital Flight, real growth rates, interest rate and exchange rate differentials have significant impact on Capital Flight, while political shock had no statistically significant impact on Capital Flight. 
Le \& Rishi (2007), using a portfolio choice model of asset allocation and econometric analysis, found that holding other determinants of capital flight constant, corruption does have a positive and significant impact on capital flight. Al-Fayoumi, et al. (2011) examines the determinants of Capital Flight in seven Middle East and North Africa (MENA) countries during the period 1981-2008. Their result which is robust to four econometrics techniques - Ordinary least Squares, Fixed effects, Random Effects, and Seemingly Unrelated Regression Model indicates that Capital Flight in MENA region is driven mainly by lagged Capital Flight, external debt, foreign direct investment, real GDP growth rate and uncertainty.

In sum, a host of factors determine Capital Flight in various climes. What these factors are in Nigeria we proceed to explore, bearing in mind that Capital Flight leads to poor growth and economic stagnation, as a result of the savings and investment gap created by the lost capital.

\section{Method}

\subsection{The Model}

Theory does not offer a sharp way of determining a priori which independent variables should be included when examining the factors that affect Capital Flight (Ndikumana \& Boyce, 2003). As such, we follow the literature and examine, in the context of developing nations, the most important variables. The significant variables captured from the literature are modeled below:

$$
\begin{aligned}
& \mathrm{CFH}=\beta_{0}+\beta_{1} L . C F H+\beta_{2} R I D+\beta_{3} G D P+\beta_{4} D B T+\beta_{5} F I S B+\beta_{6} I N F F+\beta_{7} E X R+\beta_{8} O P E N+\mu_{i} \\
& \text { Expectation } \quad+\quad+\quad-\quad+\quad+\quad+\quad+\quad+\text { + } \\
& \mathrm{CFR}=\beta_{0}+\beta_{1} L . C F H+\beta_{2} R I D+\beta_{3} G D P+\beta_{4} D B T+\beta_{5} F I S B+\beta_{6} I N F F+\beta_{7} E X R+\beta_{8} O P E N+\beta 9 P O L+\mu_{i}
\end{aligned}
$$

Where, CFH is Hot money Capital Flight; L.CFH is lagged Hot money Capital Flight; CFR is Residual Capital Flight; L.CFR is lagged residual Capital Flight; RID is real interest rate differential; EXT is exchange rate; GDP is Gross Domestic Product growth; DBT is external debt stock; FISB is Fiscal balance; INFF is inflation; OPEN is economic openness; POL is political instability; and $\mu_{\mathrm{i}}$ is the stochastic disturbance (or error) term.

\subsection{Data and Estimation}

Data for the variables in the above model, which ranges from 1970 to 2012, are sourced from the World Development Indicators (WDI) database and the Central Bank of Nigeria (CBN) Statistical Bulletin 2010. The Capital Flight variable is computed by the Hot Money approach and Residual approach earlier discussed. The political instability data is a dummy variable which has 1 for periods of political instability (all other years' aside 1979-1983 and 1999-2012) and 0 for periods of no serious political instability (1979-1983 and 1999-2012). The regression analysis is carried out using the Fully Modified Ordinary Least Square Technique (FMOLS), Seemingly Unrelated Regression (SUR) and the Error Correction Mechanism (ECM). Fully Modified Ordinary Least Squares (FMOLS) is employed to investigate long-run relationship between the dependent variable and the independent variables. The use of FMOLS requires that we establish the order of integration of the variables as well as ascertain whether or not the variables are cointegrated (Adusei, 2013). To this end, we employ Augmented Dickey-Fuller (ADF) test to investigate the order of integration of variables, and Johansen Cointegration technique to ascertain whether or not the variables are cointegrated. We further re-estimate the model using SUR method, because we are employing two measures of Capital Flight, which will yield two equations with similar set of regressors. This scenario implies there could be cross equation correlation of the residuals $\left(\mu_{i}\right)$ in the model. Thus we use the SUR model to test this and achieve more efficient estimates. This, however, warrants we have at least a different regressor in equation iii and iv, so that GLS and not OLS estimation will be applied in estimating SUR for optimal result in STATA (STATA is the econometric software used for the analysis). So in applying SUR, we include political instability (POL) in equation 4 but not in 3 above, and use the bootstrap method to achieve heteroskedastic consistent standard errors. We further employ Error Correction Model (ECM) to investigate the short-run relationship between the dependent variable and the independent variables, and also tie the short-run behavior of our dependent variables to their long-run value. The ECM first used by Sargan and later popularized by Engle and Granger corrects for disequilibrium (Gujarati, 1995). The ECM for equation iii is shown below:

$\mathrm{CFH}=\beta_{0}+\beta_{1} \Delta L . C F H+\beta_{2} \Delta R I D+\beta_{3} \Delta G D P+\beta_{4} \Delta D B T+\beta_{5} \Delta F I S B+\beta_{6} \Delta I N F F+\beta_{7} \Delta E X R+\beta_{8} \Delta O P E N+\beta_{9} \mu_{t-1}+\varepsilon i(5)$

Where $\Delta$ is a difference term used to ensure integrated time series; $\mu_{t-1}$ is lagged residual of equation iii and $\varepsilon_{\mathrm{i}}$ is the residual of the ECM with optimal properties. We estimate the ECM using Newey-West Heteroskedasticity and Autocorrelation Consistent (HAC) standard errors. 


\section{Result}

This section presents the results of empirical analysis based on ADF tests, Johansen cointegration, FMOLS, SUR and ECM methods, in order to determine the factors influencing Capital Flight in Nigeria over the period 19702012.

The Augmented Dickey-Fuller (ADF) Unit Root Test has been used to determine the order of integration of the individual variables. Table 2 displays the results of this test, and reveals that all the variables are stationary at their $1^{\text {st }}$ difference form. This lends credence to the use of FMOLS (Shahbaz, 2009).

Table 2. ADF test result

\begin{tabular}{lcccc}
\hline Variable & Test statistic & $\mathbf{1 \%}$ Critical Value & Lag & Order of Integration \\
\hline CFH & 0.497 & -3.641 & 1 & \\
$\Delta$ CFH & $-3.796^{*}$ & -3.648 & 1 & $\mathrm{I}(1)$ \\
CFR & -1.097 & -3.641 & 1 & \\
$\Delta$ CFR & $-4.398^{*}$ & -3.648 & 1 & $\mathrm{I}(1)$ \\
GDP & -2.578 & -3.648 & 2 & \\
$\Delta$ GDP & $-5.001^{*}$ & -3.641 & 2 & $\mathrm{I}(1)$ \\
INFF & -2.704 & -3.648 & 2 & \\
$\Delta \mathrm{INFF}$ & $-4.729^{*}$ & -3.655 & 2 & $\mathrm{I}(1)$ \\
EXR & 0.387 & -3.641 & 1 & \\
$\Delta$ EXR & $-3.971^{*}$ & -3.648 & 1 & $\mathrm{I}(1)$ \\
RID & -2.984 & -3.648 & 2 & \\
$\Delta$ RID & $-7.627^{*}$ & -3.655 & 2 & $\mathrm{I}(1)$ \\
DBT & -1.828 & -3.641 & 1 & \\
$\Delta$ DBT & $-5.325^{*}$ & -3.648 & 1 & $\mathrm{I}(1)$ \\
FISB & -1.787 & -3.641 & 1 & \\
$\Delta$ FISB & $-7.384^{*}$ & -3.648 & 1 & $\mathrm{I}(1)$ \\
OPEN & -3.112 & -3.641 & 1 & \\
$\Delta \mathrm{OPEN}$ & $-6.361^{*}$ & -3.648 & 1 & \\
\hline
\end{tabular}

Note: * indicates that we reject the hypothesis of presence of unit root at $1 \%$ level of significance.

We execute the Johansen Cointegration test for both equation iii and iv using a lag length of 4 selected on the basis of Final Prediction Error (FPE), Akaike's Information Criterion (AIC), Schwarz's Bayesian Information Criterion (SBIC), Hannan and Quinn Information Criterion (HQIC) and sequential Likelihood-Ratio (LR) test statistics. The result of the cointegration test for equation iii captured in table 3 below shows that there exists 2 cointegration relationships in the model, going by the trace statistic. This follows the rejection of the hypothesis of no cointegration relationship $(\mathrm{R}=0)$ and one cointegration relationship $(\mathrm{R}=1)$. The hypothesis of two cointegration relationships is accepted, as the statistic is greater than the critical value at $5 \%$. 
Table 3. Johansen cointegration test result for equation 3

\begin{tabular}{llllll}
\hline $\begin{array}{l}\text { maximum } \\
\text { rank }\end{array}$ & parms & LL & eigen value & trace statistic & $5 \%$ critical value \\
\hline 0 & 9 & -3994.2734 &. & 1504.4377 & 192.89 \\
1 & 26 & -3322.1695 & 1.00000 & 160.2299 & 156.00 \\
2 & 41 & -3295.1612 & 0.73219 & $106.2134 *$ & 124.24 \\
3 & 54 & -3271.4585 & 0.68533 & 58.8080 & 94.15 \\
4 & 65 & -3252.7852 & 0.59783 & 21.4615 & 68.52 \\
5 & 74 & -3245.4607 & 0.30043 & 6.8123 & 47.21 \\
6 & 81 & -3242.2581 & 0.14463 & 0.4071 & 29.68 \\
7 & 86 & -3242.0545 & 0.00988 & 0.0000 & 15.41 \\
8 & 89 & -3242.0545 & 0.00000 & 0.0000 & 3.76 \\
9 & 90 & -3242.0545 & -0.00000 & & \\
\hline
\end{tabular}

Note: Trend: constant. Number of obs=41. Sample: 1972-2012. Lags=1.

On the contrary, the cointegration result for equation iv, captured in Table 4 below, does not give evidence of any cointegration relationship for this equation. This implies that the condition for FMOLS is not satisfied. Thus for this equation, we resort to just SUR.

Table 4. Johansen cointegration test result for equation 4

\begin{tabular}{llllll}
\hline rank & parms & LL & eigen value & trace statistic & $5 \%$ critical value \\
\hline 0 & 9 &. & $\cdot$ &. & 192.89 \\
1 & 26 &. & 1.00000 &. & 156.00 \\
2 & 41 &. & 0.79789 &. & 124.24 \\
3 & 54 &. & 0.67788 &. & 94.15 \\
4 & 65 &. & 0.59237 &. & 68.52 \\
5 & 74 &. & 0.36310 &. & 47.21 \\
6 & 81 &. & 0.26070 &. & 29.68 \\
7 & 86 &. & 0.13189 &. & 15.41 \\
8 & 89 &. & 0.05933 &. & 3.76 \\
9 & 90 &. & 0.00000 &. & \\
\hline
\end{tabular}

Note: Trend: constant. Number of obs=41. Sample: 1972-2012. Lags=1.

Table 5 below presents the estimation results of the models of the study. From the table, the Fully Modified OLS (FMOLS) and the Seemingly Unrelated Regression (SUR) results for equation iii, which measures Capital Flight by the hot money method, show that at 5 percent level of significance, only lagged Capital Flight, fiscal balance and exchange rate are the significant long run determinants of Capital Flight in Nigeria. For the FMOLS model, the Breusch-Godfrey (BG) LM test has a p-value greater than 0.05 , which gives evidence of no serial correlation in the residuals. For the SUR model, the correlation coefficient of the residual of equations iii and iv is 0.2040 . This value, which is low, is equally proven to be nonsignificant by the Breusch-Pagan test of independence, whose probability value at 0.1862 is greater than the 5 percent level of significance. The implication is that the SUR model does not lead to significant efficiency gain, as there is no significant cross equation correlation of the residuals in equation iii and iv. The SUR model for equation iv shows that when Capital Flight is measured by the residual method (CFR), only lagged Capital Flight and exchange rate remain its significant determinants. The ECM on the other hand shows that only lagged Capital Flight influences Capital Flight in the short run in Nigeria. Although the Breusch-Godfrey (BG) LM test for serial correlation has a probability value of 0.0000 which leads to 
rejecting the hypothesis of no serial correlation, we, however, employed Newey-West method to achieve HAC standard errors. The error correction term $\left(\mu_{-1}\right)$ also has a negative and significant coefficient $(-3.84)$, indicating that there is about $384 \%$ feedback from the previous year's disequilibrium, and that every year, about $384 \%$ of the disequilibrium in Capital Flight is corrected.

Table 5. Determinants of capital flight in Nigeria

\begin{tabular}{|c|c|c|c|c|c|}
\hline Equation 3 (CFH) & FMOLS & SUR & $\begin{array}{c}\text { ECM } \\
\text { (with Newey-West } \\
\text { standard errors) }\end{array}$ & Equation 4 (CFR) & SUR \\
\hline \multirow[t]{2}{*}{ L.CFH } & $0.9246^{*}$ & $0.9031987^{*}$ & $4.5047^{*}$ & L.CFR & $0.7225515^{*}$ \\
\hline & $(0.00)$ & $(0.00)$ & $(0.00)$ & & $(0.00)$ \\
\hline \multirow[t]{2}{*}{ RID } & 4414979 & 4632736 & 5603703 & RID & 1103.159 \\
\hline & $(0.25)$ & $(0.33)$ & $(0.393)$ & & $(0.87)$ \\
\hline \multirow[t]{2}{*}{ GDP } & 496.28 & 178115.4 & 4479149 & GDP & -8520.377 \\
\hline & $(1.00)$ & $(0.97)$ & $(0.56)$ & & $(0.42)$ \\
\hline \multirow[t]{2}{*}{ DBT } & -0.005 & -0.0054 & -0.004 & DBT & -7320000 \\
\hline & $(0.25)$ & $(0.11)$ & $(0.86)$ & & $(0.17)$ \\
\hline \multirow[t]{2}{*}{ FISB } & $1721.95^{*}$ & $1695.52 *$ & 3220.95 & FISB & 0.252842 \\
\hline & $(0.00)$ & $(0.02)$ & $(0.11)$ & & $(0.91)$ \\
\hline \multirow[t]{2}{*}{ INFF } & 455616 & 633683.5 & 4951995 & INFF & 4048.74 \\
\hline & $(0.876)$ & $(0.78)$ & $(0.35)$ & & $(0.45)$ \\
\hline \multirow[t]{2}{*}{ EXR } & $6238628^{*}$ & $6537346^{*}$ & 21600000 & EXR & $5509.168^{*}$ \\
\hline & $(0.00)$ & $(0.00)$ & $(0.320)$ & & $(0.34)$ \\
\hline \multirow[t]{2}{*}{ OPEN } & 5089927 & 5359564 & 14000000 & OPEN & 4489.574 \\
\hline & $(0.19)$ & $(0.18)$ & $(0.20)$ & & $(0.48)$ \\
\hline \multirow[t]{2}{*}{$\mu_{-1}$} & & & $-3.84 *$ & POL & 62988.46 \\
\hline & & & $(0.01)$ & & $(0.72)$ \\
\hline $\operatorname{Adj} R^{2}$ & 0.9719 & & 0.2516 & Breusch-Pagan test (prob) & 0.1862 \\
\hline $\mathrm{R}^{2}$ & 0.9774 & 0.9773 & 0.4200 & $\mathrm{R}^{2}$ & 0.8669 \\
\hline F-stat (prob) & 0.0000 & 0.0000 & 0.0283 & F-stat (prob) & 0.0000 \\
\hline BG LM test & Prob $>$ F & & Prob $>$ F & & \\
\hline$(\operatorname{lag}=3)$ & 0.3901 & & 0.0000 & & \\
\hline
\end{tabular}

Note: CFH is Hot money Capital Flight; L.CFH is lagged Hot money Capital Flight; CFR is Residual Capital Flight; L.CFR is lagged residual Capital Flight; RID is real interest rate differential; EXT is exchange rate; GDP is Real Gross Domestic Product growth; DBT is external debt stock; FISB is Fiscal balance; INFF is inflation; OPEN is economic openness; and POL is political instability. In estimating the ECM, first differences of all the regressors are used. The values in parenthesis are the probabilities of the critical values. * implies the variable is significant at $5 \%$ level of significance.

\section{Discussion}

The significant, positive relationship between lagged Capital Flight and Capital Flight in Nigeria indicates that there is a tendency for hysteria in events of Capital Flight. This is consistent with the explanation presented by Ndikumana \& Boyce (2008), Al-Fayoumi et al. (2011) who argue that the significant lagged Capital Flight variable may reflect a habit-formation effect, as private actors gain experience in Capital Flight operations. It also reflects a contagion effect, as Capital Flight corrodes the legitimacy of capital controls, particularly if the flight capitalists include government authorities. More so, it informs that the devastating consequences of Capital Flight persist over time. Thus a given year's Capital Flight does not only imply lost domestic savings and investment for 
that year, but also loss of future years investments and further widening of savings gap over future years. This obtains because any given year's Capital Flight triggers further Capital Flight and the cycle continues, creating a ratchet effect. Even the nature of foreign capital inflow into Nigeria has contributed to this. In recent years, there has been appreciable level of Foreign Portfolio Investment (FPI) in Nigeria, which is higher than Foreign Direct Investment. This FPI, given Nigeria's loose capital account regulation, is susceptible to quick flight. Such flight then creates downward pressure on the exchange rate, thereby triggering even further flight from domestic portfolio investors.

Fiscal balance also has a positive and significant relationship with Capital Flight. The finding suggests that higher fiscal balance in Nigeria leads to higher Capital Flight. This finding though contrary to expectation could have some practical justification. It could be that rise in fiscal balance is accompanied by some other counter forces that limp the restraining impact of rising fiscal balance on Capital Flight. Specifically, if fiscal balance happens to rise in the face of rising ethnic/regional strife, insecurity, economic uncertainty and corruption, as has been the case in Nigeria over the years, the outcome is that these "economic evils" will most likely outweigh fiscal balance in the optimal portfolio choice/risk perception decision of individuals, thus, leading to Capital Flight in the country. In other words, it is not enough for the Nigerian government to target more austere fiscal measures and discipline; it also ought to constrain corruption, ethnic/regional strife, insecurity and corruption in the country! Without effort and result in this area, there will remain a copious confidence gap in the Nigerian economy, which will always warrant widening savings gap via Capital Flight.

Exchange rate is also a significant and positive determinant of Capital Flight in Nigeria. Rising exchange rate due to market forces (depreciation) or deliberate government policy (devaluation) presents risk of loss of capital gains for foreign investors in the Nigerian economy. Such persistent depreciation/devaluation of the domestic currency leads to loss of confidence in the economy, even amongst nationals, because higher exchange rates imply that foreign investments or funds domiciled in Nigeria will amount to lower foreign currency value. As such, investors as well as foreign profit earners, being rational individuals, are justified to seek safe haven for their funds as well as profits, before their capital gains get completely eroded. Consequently, mass exodus of capital will be recorded over time, meaning lost and missing domestic savings-investments. This finding, which supports that of Cuddington (1987), Nyoni (2000), Harrigan et al. (2002), Felding (2003) and Cerra et al. (2005), also brings to mind the Asian financial crisis of the late 1990's and the massive Capital Flight that followed the monumental exchange rate depreciation of the region. By implication, maintaining suitable balance of payment position, which helps sustain stable exchange rate is a good way to prevent Capital Flight.

\section{Conclusion}

Understanding the development constraints imposed by low domestic savings, and the role Capital Flight plays in widening this savings gap in developing nations, this paper explored the socio-economic determinants of Capital Flight in Nigeria. Using three econometric approaches, FMOLS, SUR and ECM, lagged Capital Flight, fiscal balance and exchange rate are found to be the significant determinants of Capital Flight in Nigeria.

These findings have significant policy implications for the Nigeria economy. It follows that serious efforts must be made to improve confidence in the Nigerian economy. Exchange rates have to be stabilized over time. Economic and political stability must be sought after and maintained. Ethnic/regional strife, insecurity and corruption, which have become household terms in Nigeria, must be nipped on the bud. Also economic uncertainty must be aced and a high level of economic predictability enthroned. In short, Nigeria cannot risk further Capital Flight, given the observed contagion and habit-formation effects.

The recommendation of Onwioduokit (2002) Corroborates the above: "policy measures should be instituted to make the domestic economy more attractive for private investment if capital flight is to be confronted and flight capital recaptured." Shibuya (2001) on his part makes a strong case for sequencing of liberalization and introduction of policies to combat capital flight "the economy may be trapped in low capital equilibrium if liberalization is implemented before sufficient accumulation of domestic capital." Therefore, we recommend some form of capital control, as a way of mitigating capital flight. Although this option has become less appreciated, it remains a productive option for developing nations. This does not, however, preclude creating adequate incentives to encourage investors investing and retaining capital in the domestic economy. As such, policy risks, political risks and economic risks have to be urgently tackled in Nigeria. Economic infrastructure, which is achingly decrepit in the country, should be upgraded in order to boost real domestic investment, as against capital inflows that just settle for portfolio investments, which easily fly back as capital flight. Addressing the stated risk factors and infrastructure in Nigeria, in line with proper exchange rate management will not only contribute in abating capital flight, but will also achieve flight reversal—Nigeria, being a developing nation, has high returns on 
investments.

Quelling Capital Flight in Nigeria means attenuating savings gap. But to the extent that Capital Flight remains high, domestic investment will remain very low. Poverty levels will remain high and the quest for economic development will remain a tall order. The key out of Nigeria's widening savings gap is keeping domestic capital at home, making it available for investment and augmenting it with foreign capital in the form of aid and FDI.

\section{References}

Adedeji, O. (2001). The size and sustainability of Nigerian current account deficits. International Monetary Fund Working Paper 01/87. Washington DC.

Adusei, M. (2013). Is Inflation in South Africa a structural or monetary phenomenon? British Journal of Economics, Management \& Trade, 3(1), 60-72.

Agu, C. (2006). Capital flight and domestic macroeconomic policies: Evidence from Nigeria. Unpublished $\mathrm{PhD}$ thesis. University of Nigeria, Nsuka, Nigeria.

Ajayi, S. (1992). An econometric analysis of capital flight from Nigeria. Working Paper Series No. 993. World Bank Western Africa Department, the World Bank, Washington, D.C.

Ajayi, S. (1995). Capital flight and external debt in Nigeria. African Economic Research Consortium, Nairobi. Resaerch Paper No. 35.

Ajilore, T. (2010). An economic analysis of capital flight from Nigeria. International Journal of Economics and Finance, 2(4), 89-101.

Al-Fayoumi, N., Alzoubi, M., \& Abuzayed, B. (2011). Determinants of capital flight: Evidence from MENA countries. Paper presented at the Barcelona European Academic Conference. Retrieved from http://www.conferences.cluteonline.com/index.php/IAC/2011SP/paper/viewFile/438/444

Bender, D., \& Lowenstein, W. (2005). Two-gap models: Post-keynesian death and neoclassical rebirth. IEE Working Papers, 80.

Bouchet, M. (2012). Capital flight in Vietnam 1977-2011: A country risk analysis of the root causes of expatriated savings. SKEMA Business School: Global Finance Center.

Central Bank of Nigeria. (2010). Annual Report.

Cerra, V., Rishi, M., \& Sweta, S. (2005). Robbing the Riches: Capital flight, institutions, and instability. IMF Working Paper No. 199.

Chang, P., \& Cumby, R. (1991). Capital flight in Sub-Saharan African countries. In I. Husain \& J. Underwood (Eds.), African External Finance in the 1990s. Washington, D.C.: The World Bank.

Cline, W. (1987). Mobilizing Bank Lending to Debtor Countries. Washington, D.C., US: Institute for International Economics.

Cuddington, J. (1986). Capital flight estimates, issues and expenditures. Princeton Studies in International Finance, 58.

Cuddington, J. (1987). Macroeconomic determinants of capital flight: An econometric investigation. In D. Lessard \& J. Cuddington (Eds.), Capital Flight and Third World Debt. Washington: Institute for International Economics.

Eggerstedt, H., Hall, R., \& Wijinbertgen, S. (1995). Measuring capital flight: A case study of Mexico. World Development, 23(2), 211-232. http://dx.doi.org/10.1016/0305-750X(94)00123-G

Erbe, S. (1985). The flight of capital from developing countries. Intereconomics, 20(4), 268-275. http://dx.doi.org/10.1007/BF02925467

Fatehi, K. (1994). Capital flight from Latin America as a barometer of political instability. Journal of Business Research. 30. http://dx.doi.org/10.1016/0148-2963(94)90037-X

Felding, D. (2003, June). How does civil war affect the magnitude of capital flight? Evidence from Israel during the intifada. Department of Economics, University of Leicester and WIDER, United Nations University, Helsinki, second draft.

Galizia, F., \& Steinberger, T. (2001). The "savings gap" of European Corporations: A first look at the available data. Konrad Adenauer, Luxembourg: European Investment Bank.

Gujarati, D. (1995). Basic econometrics (3rd ed.). New York, America: McGraw-Hill Higher Education. 
Harrigan, J., Mavrotas, G., \& Yusop, Z. (2002). On the determinants of capital flight: A new approach. Journal of the Asia Pacific Economy, 7, 203-241.

Henry, L. (1996). Capital flight from beautiful places: The case of three caribbean countries. International Review of Applied Economics, 10(2), 263-272. http://dx.doi.org/10.1080/02692179600000019

Kahn, M., \& Hague, N. (1987). Foreign borrowing and capital flight: A formal analysis. IMF Staff Papers, 32(4), 606-28. http://dx.doi.org/10.2307/3866741

Kindleberger, C. (1987). Capital flight: A historical perspective. In D. R. Lessard \& J. Williamson (Eds.), Capital Flight and Third World Debt. Washington, D.C.: Institute for International Economics.

Le, Q., \& Rishi, M. (2006). Corruption and capital: An empirical assessment. International Economic Journal, 20(4), 523-540. http://dx.doi.org/10.1080/10168730601027161

Lessard, D., \& Williamson, J. (1987). Capital flight and third world debt. Washington, D.C.: Institute for International Economics.

Maniak, G., \& Milaszewicz, D. (2008). Investment Processes in Poland after 1990. Int. J. of Economic Policy in Emerging Economies, 1(2/3), 228-247. http://dx.doi.org/10.1504/IJEPEE.2008.019266

Morgan Guaranty Trust Company. (1986). LDC capital flight. World Financial Markets, 2(March), 13-6.

Ndikumana, L., \& Boyce, J. (1998). Congo's odious debt: External borrowing and capital flight in Zaïre. Development and Change, 29(2), 195-217. http://dx.doi.org/10.1111/1467-7660.00076

Ndikumana, L., \& Boyce, J. (2003). Public debts and private assets: Explaining capital flight from Sub-Saharan African countries. World Development, 31, 107-130. http://dx.doi.org/10.1016/S0305-750X(02)00181-X

Ndikumana, L., \& Boyce, J. (2008). New estimates of capital flight from Sub-Saharan African countries: Linkages with external borrowing and policy options. University of Massachusetts, Political Economy Research Institute, Working Paper No. 166.

Nyatepe-Coo, A. (1994). Capital flight in low-income Sub-Saharan Africa: The effects of political climate and macroeconomic policies. Scandinavian Journal of Development Alternatives, 13(4), 59-68.

Nyong, M. (2003). Capital flight and economic growth in Four African Countries. Nigeria, Cote D'ivoire, Morroco and Ghana. DMO Monthly Seminar Series, 2.

Nyoni, T. (2000). Capital flight from Tanzania. In S. Ajayi \& S. Mohsin (Eds.), External Debt and Capital Flight in Sub-Saharan Africa. International Monetary Fund.

Ojo, O. (1992). An empirical investigation of capital flight in selected African Countries. Economic Research Papers, 17.

Onwioduokit, E. (2001). Capital flight from Nigeria: An empirical re-examination. Paper presented at WIDER Development Conference on Debt Relief, Helsinki, Finland, 17-18 August.

Onwioduokit, E. (2002) Capital flight from Nigeria: An empirical re-examination. Accra, Ghana: West African Monetary Institute.

Shahbaz, M. (2009) Reassessment of finance-growth nexus for Pakistan: Under the investigation of FMOLS and DOLS techniques. The ICFAI J. Applied Econ., 8(1), 65-81.

Shibuya, H. (2001). Economic takeoff and capital flight. Economic and Social Research Institute Discussion Paper No.8 December, Cabinet Office Tokyo, Japan.

Skare, M., \& Sinkovic, D. (2013). The role of equipment investments in economic growth: A cointegration analysis. Int. $J$. of Economic Policy in Emerging Economies, 6(1), 29-46. http://dx.doi.org/10.1504/IJEPEE.2013.054471

Walter, I. (1987). The mechanisms of capital flight. In D. R. Lessard \& J. Williamson (Eds.), Capital Flight and Third World Debt. Washington, D.C.: Institute for International Economics.

World Bank. (1985). Case study: Mexico. In D. R. Lessard \& J. Williamson (Eds.), Capital Flight and Third World Debt. Washington, DC: Institute for International Economics. 


\section{Copyrights}

Copyright for this article is retained by the author(s), with first publication rights granted to the journal.

This is an open-access article distributed under the terms and conditions of the Creative Commons Attribution license (http://creativecommons.org/licenses/by/3.0/). 